\title{
Displacement or composition? Lyotard and Nancy on the trait d'union between Judaism and Christianity
}

\author{
Frans van Peperstraten
}

Received: 21 January 2008 / Accepted: 6 May 2008 / Published online: 10 June 2008

(C) The Author(s) 2008

\begin{abstract}
In one of the essays in his recent book on Christianity, La déclosion (2005), Nancy discusses the relationship between Judaism and Christianity. Nancy opens this discussion with a reference to Lyotard's book on this relationship: Un trait d'union (1993). Both Lyotard and Nancy examine a very early figure in the emergence of Christianity from Judaism - whereas Lyotard focuses on the epistles of Paul, Nancy reads the epistle of James. Lyotard concludes that the hyphen in the expression 'JudeoChristian' actually conceals 'the most impenetrable abyss within Western thought'. With this abyss, Lyotard refers to the point of departure of Judaism: the event in which a Voice has left behind letters, inaugurating an interminable work of interpretation. For Nancy, however, it is rather Christianity, and therefore, Western culture, which is deconstructive in nature. Its composition is co-original with a decomposition, and therefore, with an openness. In James, Nancy finds an emphasis on praxis, in such a way that existence is to be understood as transcendent within itself. With this reading of James, Nancy seems to deny that there is a fundamental difference between Judaism and Christianity. In order to clarify the differences between Lyotard and Nancy, it is shown that, in Lyotard's view, an unsublatable alterity comes with aisthèsis, whereas in Nancy's view, alterity comes with existence as such.
\end{abstract}

Keywords Alterity $\cdot$ Christianity $\cdot$ Judaism $\cdot$ Lyotard $\cdot$ Nancy $\cdot$ Praxis $\cdot$ Sensation

\section{Introduction}

The fact that every culture finds itself confronted with a certain alterity has become increasingly topical in contemporary philosophical discussion. Generally,

F. van Peperstraten $(\bowtie)$

Tilburg University, Room D 239, P.O. Box 90153, 5000 LE Tilburg, The Netherlands

e-mail: F.T.vPeperstraten@uvt.nl 
philosophers recognize the danger of simply locating this alterity outside of the specific culture by projecting it onto an exceptional group of people. The acknowledgement that alterity is present within each and every culture, within each and every constituent group thereof, even within each individual, then gives rise to the question of how this alterity should be conceived of.

Lately this question has become ever more frequently posed with regard to religion. Which is surprising, at any rate for Europe, for until not so long ago it seemed that European culture was firmly set on an atheistic course. Particularly the establishment of a strong Islamic presence in Europe has however resulted in significant renewed interest in the roots of European culture, whether religious or not.

Against this background, Jean-Luc Nancy's recent book, Dis-Enclosure: The Deconstruction of Christianity, ${ }^{1}$ makes a welcome appearance. Nancy's points of departure are, on the one hand, that Christianity and Western culture may be equated with one another; on the other, that Christianity finds itself within a process of deconstruction. This deconstruction does not refer to an external operation which is brought to bear upon Christianity, but rather, according to him, to a gesture which is intrinsic to Christianity itself. Christianity, according to Nancy, means nothing else but 'the requirement to open up in this world an unconditional alterity or alienation' (D 20).

Unfortunately, Nancy merely touches on the subject of the relationship between Christianity and Islam. However, in one of the essays in this volume-'Le judéochrétien (De la foi)' ('The Judeo-Christian (Of Faith)')—he does comprehensively address the relationship between Christianity and Judaism. In Nancy's treatment, Judaism not so much represents a distinct religion outside of Christianity, but rather an element of the alterity which, according to him, is intrinsically constitutive of Christianity as such.

With regard to the relationship between Judaism and Christianity, such a reading invites the drawing of a comparison between Nancy and Jean-François Lyotard. After all, in the introduction to his text, Nancy quotes a phrase which was used by Lyotard in his The Hyphen (1999) in reference to the relationship between Judaism and Christianity: 'the most impenetrable abyss that Western thought conceals'. ${ }^{2}$ While Nancy

\footnotetext{
${ }^{1}$ As I was writing this article, this English translation of Nancy's book-originally: La Déclosion (Déconstruction du christianisme, 1), Galilée, Paris 2005-was announced, but had not appeared yet. Therefore, references to this book are based on the French original, and are indicated in the text by ' $\mathrm{D}$ ', followed by the relevant page number(s). The English translations in this article are my own.-In addition to the 'Overture' which was specifically written for this volume, the book contains a collection of 14 texts initially presented as lectures. A few of them have also been published before. The oldest text dates back to 1995 ; the remaining ones all date from after 2000.

2 This book, which was co-authored by Eberhard Gruber, originally appeared as Un trait d'union, Le Griffon d'argile, Sainte-Foy (Québec) and Presse Universitaires de Grenoble, 1993. Four texts are contained in this volume: first of all, two essays by Lyotard: 'Mainmise' and 'On a Hyphen', which have previously appeared separately in print (in respectively 1989 and 1992), and which were later also included in Lyotard's posthumously published Misère de la philosophie (Galilée, Paris 2000); then a commentary which Gruber wrote in 1993, entitled 'A trait is not all there is to it', and in conclusion, a letter which contains Lyotard's reaction to Gruber. This however does not conclude the interaction between Lyotard and Gruber. The English edition (Lyotard 1999) contains two additional texts: a letter in which Gruber-already in 1993 - replies to that of Lyotard, and Gruber's minutes of a conversation which took place between Lyotard and himself in January 1995. For the remainder of this article, this English edition will be referred to as 'TH', followed by the relevant page number(s). See TH 13 for the phrase quoted by Nancy.
} 
appears to look favourably on this critical statement, it turns out that his evaluation of the relationship between Judaism and Christianity is completely different to Lyotard's. As we will see, this difference in their views is related to their different approaches with regard to the issue of alterity.

\section{Lyotard on Paul's hyphen}

From the end of the 1960s, when after his period of activism he returned to philosophy, Lyotard has repeatedly and intensively explored Judaism. For Lyotard, Judaism represents a counterpoint to Western culture. While his more detailed analyses of the relationship between Judaism and the West bear witness to those shifts which have occurred (from 1968 to 1998) in his thinking in general, the central thrust of Lyotard's evaluation has remained constant: Judaism contains the necessary critique of an illusion which has profoundly determined Western culture, one which may be defined as the illusion of presence, fulfilment and totality: 'May I confide in you here that, under the name "Jew", I am looking for that which tarnishes and leaves in mourning (and indeed must do so) this Western accomplishment?', Lyotard writes to his interlocutor Gruber (TH 57). ${ }^{3}$

What is then, according to Lyotard, the character of Judaism? How can a critique of Western culture be derived from it? Let us start by cautiously scouting out the terrain, by means of an anecdote Lyotard tells about Levinas. A Catholic prelate once asked Levinas: 'You are our fathers, that's clear, but what do you really believe in?' Levinas responded: 'Your eminence, we do not believe, we have a Book. As it is written, the voice of the Saint, blessed though he may be, inspires more questioning (and the anxiety of questioning) than confidence' (TH 78). This anecdote serves to illustrate that Judaism seizes upon a text which is radically open to interpretation rather than upon a defined belief-content.

The reason why this text should be considered as radically open to interpretation, is illustrated by a story by Gershom Scholem which was related to Lyotard, and which he evidently found to his liking: What exactly happened when the Ten Commandments were revealed on Mount Sinai? Put more precisely: what was being heard-by Moses on the one hand, and by the people of Israel on the other? To be sure, all would have heard the Divine Voice. But there is the story that the people of Israel only heard the first two Commandments, namely: 'I am the Lord your God' and 'You shall have no other gods before me'. 4 This experience would already have exceeded the people's faculties of comprehension; only Moses was therefore still able to 'endure' receiving

\footnotetext{
3 An overview of other texts in which Lyotard provides a characterisation of Judaism in order to play it off against Western culture: 1. 'Figure forclose' (written in 1968, published in 1983). 2. 'Oedipe juif' (1970). 3. 'Sur une figure de discours' (1972). 4. Le mur du pacifique (1977). 5. 'Discussions, ou: "Phraser après 'Auschwitz"”' (1981). 6. Le différend (1983). 7. Heidegger et “les juifs” (1988). 8. 'Survivant' (1991). 9. Chambre Sourde (1998). The amount of secondary literature is overwhelming. I therefore limit myself to a single reference: Elisabeth de Fontenay's, Une toute autre histoire. Questions à Jean-François Lyotard, Fayard, Paris 2006 - a book which is entirely dedicated to Lyotard's treatment of Judaism, and which itself introduces an historical perspective - that is, of actual Jews in history.

4 The New International English Version of the Bible. This Version will be used throughout this article.
} 
the remaining Commandments. Another story takes this even further: the people of Israel heard nothing but 'the aleph with which in the Hebrew text the first Commandment begins, the aleph of the word "anochi", "I". 'In Hebrew', writes Scholem, 'this aleph represents nothing but the glottal stop which precedes a vowel at the beginning of a word (as with the Greek spiritus lenis). Thus, the aleph is, so to speak, that element from which every articulated sound originates. (...) To hear the aleph is as good as hearing nothing; it is rather the transition to all perceptible language' ${ }^{5}$ In other words, the people did hear the initial impetus to what they were supposed to understand, but they did not know what they should have understood.

It is this thought which is singled out by Lyotard in his The Hyphen as Judaism's point of departure. In his view, Christianity replaces this point of departure with a substantially different one. As a result, the structure of his argument is broadly as follows: he provides an outline of what he considers to be the essence of Judaism, and he then investigates the mutation brought about by Christianity's apostle Paul of Tarsus through his letters to the fledgling Christian communities in, amongst others, Corinth, Galatia and Rome. ${ }^{6}$ From Lyotard's outline of Judaism, on the one hand, and its Pauline-Christian mutation, on the other, I would like to draw out four elements for discussion:

1. A Voice (Lyotard's capitalization) has left behind letters on the stones of the desert. No vowels are to be found amongst these letters, and the letters themselves are as yet unvoiced. A people, Lyotard explains, becomes constituted by taking upon itself the obligation to act out these letters, that is, to vocalize them, to give voice to them, to track down their meaning and carry it out.

In Lyotard's view, the Voice leaving behind these letters signifies an exceptional kind of event. An event such as this opens up a peculiar kind of historicity. What is relevant here is not the mythical history or the story in general, where the end is identical to the beginning, or at any rate 'rhymes' with the beginning. Of just as little relevance is the modern consciousness and its pretence to constitute the three modes of time from within itself. After all, the beginning, that is the Voice, arrives into, but does not find itself within current time. To act upon the letters in current time implies that the Voice 'itself' has withdrawn itself from it. Reality, as it has been given with the letters, is unfulfilled, which causes the people to go in search of justice. Thus, according to Lyotard, the people interrupts the mythical, and invents the ethical point of view (TH 13).

According to Lyotard, another point of departure applies with regard to Paul. Paul places the incarnation in, and especially the resurrection of, Jesus Christ at the centre of history. Against this point of reference history acquires a 'then', a 'before then'

\footnotetext{
5 Gershom Scholem quoted by Elizabeth Weber in her conversation with Lyotard, in Weber (1994, p. 161).

6 In this same discussion with Weber Lyotard sheds light on his interest in Paul: he remarks that the actual influence of Greek thought on Western philosophy is often overestimated and that Western metaphysics are much rather, and to a greater extent, founded in Christianity—and then specifically through Paul, who appropriated from Greek thinking only such elements as he found to his liking. According to Lyotard, the true father of Western metaphysics is Paul. Lyotard adds: 'this Paul was a Lenin!' (ibid., 169). Also Alain Badiou-in the preface to his book Saint Paul. The foundation of universalism (Stanford University Press, 2003; originally 1977)_draws an analogy between Paul and Lenin: both as militant figures, but in the service of respectively Christ and Marx.
} 
and an 'after then'. Within this historicity, God's presence to mankind, and therefore also the present tense, becomes the measure of things. This however does not mean that Lyotard concludes that Christianity and modernity coincide. The three modes of time are not as yet grasped on the basis of consciousness. Rather, in Lyotard's reading of Paul, man can only participate in the presence of God, after first having allowed himself to become dispossessed of himself. Modernity, on the other hand, according to Lyotard, no longer requires any dispossession. Christianity means that man becomes 'taken into possession by' (Mainmise: the title of one of Lyotard's texts in this volume) an alterity, whereas modernity holds that one can be freed from all indebtedness to the other (TH 4).

2. According to Genesis 22, God instructed Abraham to sacrifice his son Isaac. But, after he had already tied up his son and placed him on the sacrificial altar, Abraham was told by an angel that he should do the lad no harm, for he (Abraham) had been tried sufficiently. By drawing an analogy between the bond around the body of Isaac and the 'bond' which ties the signifier to the signified, Judaism, according to Lyotard, concludes from this incident that also the bond with which the letters are tied to their meaning is unstable - in as far as it can be severed by God at any moment. The text may always turn out to mean something different to what it was thought to mean, and therefore it has to be reread continuously. This is why Judaism attaches such enormous importance to the endless work of interpretation (TH 10-11).

In his outline of Judaism, Lyotard also refers to the Judaic tradition of assigning four different types of meaning to the text of the Torah: first of all, literal or evident meaning; secondly, allegoric or metaphoric meaning; thirdly, moral meaning, which can be drawn from the text in the light of factual experiences; and, in conclusion, secret or inaccessible meaning. It is as a result of this last type of meaning that the Voice always remains withdrawn, and therefore also continues to provoke desire (TH 14).

Judaism first and foremost differentiates itself from Christianity through the recognition of this fourth type of meaning, termed sod in Hebrew-and rendered by Lyotard as estrangé in French. In this text he also frequently makes use of the noun estrangement. It may be assumed that Lyotard has deliberately chosen these uncommon terms, as alternatives to aliéné and aliénation. These latter terms are normally employed in dialectical thinking, where 'alienation' is conceived of as something which can in principle be resolved —or put in Hegelian terminology: sublated - through an act of reappropriation. When choosing for the word estrangement, Lyotard indicates that Judaism recognizes that this is an irresoluble condition. However, the fact that estrangement cannot be resolved, does not preclude humanity from relating towards it. Drawing, for instance, on his 'Rewriting modernity', one may assume that Lyotard here has the Freudian term Durcharbeitung in mind, even though he does not explicitly mention it as such. ${ }^{7}$ Such processing, 'working through' must however be distinguished from that form of recollection which completely restores the matter to presence.

Yet Paul, according to Lyotard, doesn't accept this relationship towards a definitively estranged Voice. For this reason he appeals to incarnation and transfiguration. The incarnation in Jesus Christ means that the Voice had become flesh, and had come

\footnotetext{
7 See Lyotard (1991, pp. 24-35) (originally published as L'inhumain, Galilée, Paris 1988).
} 
amongst us 'once and for all' (Rom. 6:10). The Judaic estrangement is therefore replaced by the Christian incarnation. Paul develops a dialectic of life and death, which, according to Lyotard, is also a dialectic of dispossession (dis-appropriation) and appropriation. Paul writes: 'I have been crucified with Christ and I no longer live, but Christ lives in me. The life I live in the body, I live by faith in the Son of God, who loved me and gave himself for me.' (Gal. 2:20). Faith ruptures the self-love of the faithful, but simultaneously endows the faithful with the love of Christ. In transfiguration the bread and wine become signifiers of the actual presence of Christ. According to Paul, the bond with the signified is thereby guaranteed, which means that the endless work of interpreting the letters has become superfluous. ${ }^{8}$ This brings into being a dialectic of love, upon which, according to Lyotard, Christianity is founded: here I am, in flesh, come (TH 23-24). Desire is replaced by love.

Lyotard contradicts this dialectic with which Paul sought to transform Judaism into Christianity, this dialectical opposition between death and life, between reading and love. The language of the Other, writes Lyotard, is not dead, but strange. This estrangement needs to be respected. The letters must be deciphered, vocalized, put into rhythm and sung, interpreted and translated. But their figuration is forbidden; as is the incarnation and yielding to the temptation of rendering the Voice itself audible and visible (TH 24). There should be no transfer onto the imaginary of presence (TH 60). 3. In Judaism the flesh has an ambiguous status in relation to the law. On the one hand, the flesh is held to be incompatible to the law. The flesh is abject in relation to the law, because it is unsuitable as its subject, it cannot be definitively subordinated to the law. The law curses the flesh. Whence the numerous prescriptions and markings with regard to the flesh, such as those concerning diet and circumcision. In contrast, Paul makes it clear to his readers that the true nourishment is the body of Christ- 'Now you are the body of Christ, and each one of you is a part of it' (1 Cor. 12:27) — and that true circumcision is spiritual in nature (Rom. 2:29). In Paul's view then, this incompatibility has in principle been resolved (TH 19-20).

On the other hand though, Judaism considers the flesh as a medium by which the law is transmitted. Judaism, the law, is transmitted by means of the 'flesh', firstly, through acts of physical procreation; secondly, through instruction in the letters. Against the first, procreative mode of transmission, Paul objects that in Judaism the law is reserved to the offspring of those who are already encompassed by the law anyway. Paul then turns the matter on its head: not those who descend from the elected through their flesh belong to God, but rather those who through their faith belong to God, are of His flesh. According to Paul, all those who believe may be considered the sons of Abraham, whereby the promise (according to Genesis 22:18) made to 'Abraham and his offspring'9 (Rom. 4:13) contains a blessing 'to all nations' (Gal. 3:8), 'without

\footnotetext{
8 The etymology of the word 'religion' has been debated over for centuries. Two etymological Latin sources are generally put forward: 1. relegio from re-legere (to read together again, to reread, to reconsider carefully, to go over again) and 2. from re-ligare (to bind, to bond, to return to bondage, to unite). The second explanation is more customary; it is also the one most suited to Christianity, to the belief in a fixed bond between signifier and signified. The first one, on the other hand, is better suited to Judaism: because the 'bond' is unstable, we are thrown back into the task of endless rereading.

9 In the King James version, the word 'seed' is used instead of 'offspring'. The New International English version also refers to 'seed' in Galatians 3:16.
} 
difference', and 'apart from the law' (Rom. 3:21-22). To Paul, the meaning of the word 'offspring' ('seed') culminates in Jesus Christ (Gal 3:16). Faith, not in a God who left behind His law, but in the living singularity of Jesus Christ, forges a bridge towards a universal transfer (TH 19).- The fact that instruction in the letters, the second mode of transmission, can be regarded as 'by means of the flesh', may sound strange, but Lyotard explains this by referring to the 'opaque flesh of the letters', and to the endowment of 'sonorous flesh' to the letters by vocalizing them (TH 60). Here Paul's critique can be discerned in his equation of being 'watched over by the law' with being 'under a schoolmaster'. The fact that we need to be instructed, makes children of us, minors, and in other words slaves (Gal. 3:23-4:7). Paul wants to replace this with another kind of servitude: 'offer them in slavery to righteousness leading to holiness' (Rom. 6:19), 'set free from sin and (...) become slaves to God, the benefit you reap leads to holiness, and the result is eternal life' (Rom. 6:22). In the eyes of Paul, faith in Christ means a liberation from the guardianship which is exercised in the name of the law (TH 20-21).

4. In Judaism justice is a matter of desert; it is the reward for works. Since the letters must be acted out, works are required-which are rewarded by God to the extent that they are faithful to the letters, to the law. According to Paul however, works are unsuitable to provide a foundation for justice. Nobody can ever lay claim to having satisfied the numerous precepts of the law with his or her works. Therefore it would be improper to base reward on the works. To Paul, Abraham cannot be called just because of his works, but solely as a result of his faith in God (Rom. 4:2-3; TH 17). With the coming of Jesus Christ it becomes definitively evident to Paul that justice is not regulated through law and works, but through faith in Jesus Christ. In Paul's conception, this faith is something immediate. To have faith in the incarnation, in the resurrection and the transfiguration, requires neither Jewish 'signs', nor Greek 'wisdom' (1 Cor. 1:22). - Paul simply puts it: 'Don't you know that you yourselves are God's temple and that God's Spirit (pneuma) lives in you?' (1 Cor. 3:16; TH 23).

In Lyotard's understanding, Paul's epistles come down to the placing of a hyphen between two separated terms: 'Judeo' and 'Christian'. This hyphen is dialectical in nature. Its model is given with Paul's statement that the Jew becomes truly realized in the Christian. For, as Lyotard summarizes Paul's reasoning: with only his letters, the Jew is surrounded by death, but in the flesh of Christ he is brought to life. Slavery under Judaic law is overturned by Christian faith. The endless work of Judaism is replaced by Christian faith and love. And so forth. Therefore Paul both speaks of 'rejecting' as well as 'accepting' the Jews (Rom. 11:15; TH 22). For Paul it is clear that Jews ought to convert to Christianity. Lyotard therefore concludes that Paul's trait d'union does not represent the connecting of two things of equal worth, but a dialectical trait from law to faith, and from Abraham to Jesus Christ (TH 15). Lyotard remarks that Paul wants to have us believe that the Torah is merely preparatory to a new Voice, that of Jesus Christ. Such a dialectic, according to Lyotard, is clearly derived from Greek thinking — despite Paul's claim that faith has no need of Greek 'wisdom'. The hyphen in question, says Lyotard, therefore actually needs to be viewed as one between 'Graeco' and 'Christian'. Lyotard thus also posits a trait d'union; one between Greek philosophy and Christian faith. He refers to 'the Graeco-Christian theme of a dialectic between the Old and New Covenants' (TH 57). 
It is clear that Lyotard rejects the dialectical model of thinking. He seems to have specifically Hegel in mind. Hegelian dialectics hold that the less developed can be 'sublated' in the more developed-a movement in which the standards of the 'more developed' are brought to bear on the 'less developed'. Lyotard therefore argues that Judaism as such is no longer present in the Pauline trait d'union; the hyphen 'itself' is Christian, or Graeco-Christian. Judaism is 'taken along' by the hyphen only by means of being rejected or repressed. The line (trait), says Lyotard, crosses out a blank space (un blanc) (TH 13). In Lyotard's view, this blank space is to be seen as an abyss. Thus, according to Lyotard, Paul fails to appreciate the abyss which separates Judaism from Christianity. Lyotard's thesis is 'that the text of the Gospels, the Acts of the Apostles, the Letters, and Revelation is not of the same literal, "literary", and thus ontological regimen as that of the Pentateuch' (TH 25). Lyotard could also have added the regimen of historicity and time, for also on this point we have seen how different Judaism and Christianity are orientated. Lyotard accentuates the ontological difference as 'an ontological mutation in the relationship between the visible and the audible' (TH 78).

When we now examine why Judaism and Christianity are so different, we arrive at a second abyss which Lyotard appears to have exposed. There is not only the abyss between Judaism and Christianity as such, but also the abyss that lies at the very foundation of Judaism. Lyotard has elucidated this abyss by, amongst other things, referring to the distinction between the Voice and its voiceless letters on the stones of the Sinai desert, the distinction between the letters and their meaning, and the distinction between the law and the flesh. This fundamental abyss was indicated by Lyotard with the word estrangement (see point 2 above).

When we look at other texts written by Lyotard in the same period, it becomes clear that this estrangement, as he sees it, is an inevitable aspect of aisthèsis. Since the publication of his major work, The differend (Le différend, 1983), Lyotard increasingly became a thinker of aisthèsis. Lyotard uses this Greek term, for it conjoins the meanings of perception and feeling. Man is always affectively touched in perception; his feeling indicates that something has taken place, but this feeling cannot be expressed by an articulated statement, susceptible to knowledge and communication, without becoming distorted. A complete articulation is impossible, because, according to Lyotard, there is no aisthèsis without anaesthesia. Aisthèsis is a bolt of lightning, a shock, which paradoxically desensitizes us to what we are feeling. We are always trailing behind aisthèsis, we are forever trying to get a grip on what it was that had touched us. That with which aisthèsis started remains beyond reach, and therefore we can call it both the estranged aisthèsis and the aisthèsis of estrangement.

This aisthèsis is the point of departure which Lyotard encounters in Judaism. In the very first lines of the essay 'On a Hyphen', he says that he will be speaking 'as a novice - taking the risk of approaching a suffering of the breath and of the flesh' (TH 13). Clearly, the breath corresponds to the Voice, and the flesh to the letters and to that upon which they are inscribed. Lyotard refers to a suffering which affects man, but which cannot be made completely present. The only 'reality' which can adequately link up with this aisthèsis, is an ethics of works which is based on the recognition that even the works are unable to yield adequate fulfilment. In Christianity, however, such an aisthèsis is replaced by a substantial participation in the spirit-whereby an ethics of faith and love becomes sufficient. 
As was mentioned, Lyotard refers to 'the most impenetrable abyss that Western thought conceals'. In my opinion, Lyotard has in mind the abyss which I have uncovered as the second one, but which in actual fact is the more fundamental one: the abyss or the estrangement as felt in aisthèsis. Only in as far as Judaism recognizes this primary abyss, but Christianity does not, an abyss exists also, as a secondary phenomenon, between Judaism and Christianity. This secondary abyss between Judaism and Christianity is clear enough, whether it remains as a blank space, or is traversed by a hyphen. But what remains concealed is a deeper abyss, namely one which opens up where 'Jewish' aisthèsis commences. It is this abyss which is most impenetrable to Western thought. For Western thought has mainly opted for knowledge and communication, and therefore has never taken seriously aisthèsis, nor the estrangement it entails. According to Lyotard, the same is true of Paul, for Paul wants to base himself on a dialectic of truth. ${ }^{10}$ And where this dialectic - be it with a blend of rejection and acceptance-could still come to grips with the abyss between Judaism and Christianity as such, it is completely inadequate where the primary abyss, that of estrangement, is concerned. Consequently, Lyotard concludes his thinking on aisthèsis with an adage directed against dialectics: 'there is some unsublatable' [il y a de l'irrelevable] (TH 58, 79).

\section{Nancy on openness in James}

Before discussing Nancy's treatise on the 'Judeo-Christian', I want to indicate briefly what is at stake in La Déclosion as a whole. To that end, the oldest text contained in this book is quite useful: 'La déconstruction du christianisme'. ${ }^{11}$ Here Nancy makes the observation that Christianity is subject to what has recently been termed 'the end of ideologies' (D 206-207). According to Nancy, this 'ending' is not a recent and external phenomenon; it is something which has always been inherent to Christianity. Nancy quotes Gauchet: Christianity is ‘the religion of leaving religion' (D 213). Christianity surpasses itself from within itself - in what may be termed a movement of autodépassement (D 206). Nancy discerns two sides to Christianity. On the one side, the 'closure' of which Western philosophy ('metaphysics') has been guilty, is repeated in Christianity. On the other side though, Christianity implies the constitution of a subject 'in opening'. This opening implies a deconstruction. To Nancy, Christianity is essentially deconstructive in nature. He ventures to make the remarkable statement that, also conversely, deconstruction is Christian. And he even goes so far as to state that deconstruction is only possible within Christianity (D 216-217).

\footnotetext{
10 Lyotard's view on Christianity is not always as negative as in The Hyphen. Thus, in The Confession of Augustine (Stanford University Press, 2000) he acknowledges that Augustine treats corporeal experience (which means aisthèsis) as something overwhelming, corresponding to a lasting strangeness within the subject.

11 'La déconstruction du christianisme', originally given as a lecture in 1995, already appeared in print in 1998. The title of this lecture has become that of Nancy's project as a whole, of which La Déclosion is evidently only the first part. A number of separate publications-for instance Visitation (de la peinture chétienne), Galilée, Paris 2000 and Noli me tangere, Bayard, Paris 2003 - may in fact also be seen to form part of this project. His Au ciel et sur la terre (Bayard, Paris 2004) provides a very lucid introduction (because written for children).
} 
It should however be kept in mind here that Nancy never strictly delimits Christianity from other monotheistic religions, neither from philosophy, nor from Western culture as a whole. On the contrary, he views Christianity as both the integration and autodépassement of the Judaic, Hellenic and Roman heritage (D 212). In another text in this volume Nancy points out that Christianity is a composite-both historically as well as in terms of dogma (D 57).

Nancy also emphasizes Christianity's composite nature in 'Le judéo-chrétien (De la foi)' ${ }^{12}$ the text we will now be focusing on in some detail. At the outset of the text, Nancy provides a brief inventory of the meanings which have been assigned to the term 'Judeo-Christian'. He then proceeds to remind us that, with regard to the trait d'union in this term, Lyotard had spoken of 'the most impenetrable abyss that Western thought conceals'. With regard to Lyotard's actual views on the relationship between Judaism and Christianity, Nancy however refrains from providing explicit commentary. He seems to prefer providing such commentary in an indirect way.

Nancy appears to echo Lyotard by saying that the trait d'union by which the composition is bound together simultaneously decomposes it at its centre, making this centre into a separation (désunion). Nancy refers to 'the enigma of this uncomposable composition' (D 66). According to him, when saying 'Judeo-Christian', we not only mention two elements within Western civilization, we moreover simultaneously introduce the issue of this civilization's composition and decomposition. First of all, even when this expression only contains names of religions, it implicitly also refers to philosophy as a non-religious component of Western culture. And in as far as philosophy refers to the ancient Greeks, the 'Judeo-Christian' can by extension be called 'Judeo-Graeco-Christian'. Besides, Judaism and Christianity have had an influence on the birth of Islam, the third of the three 'religions of Scripture'. All three religions have furthermore broken up into a multitude of forms. In short, Nancy concludes, 'the Judeo-Christian composition' comprises 'the general dis-position of the West' (D 67).

Nancy does not limit himself to merely providing a genealogy of this Western disposition, he also indicates how it should be thought as such. The 'Judeo-Christian composition' is structured according to a schema which plays a significant role 'in our entire tradition of thought', namely the schema of the coincidentia oppositorum. He explains that variations of the coincidentia oppositorum keep on reappearingfor instance in the oxymoron, in Kantian schematism, in Hegelian dialectics, and in mystical ecstasy (D 67). Elsewhere in this volume Nancy supplements this list by adding - amongst others - the dialogues of Plato, Derrida's aporia, and Kant's antinomies of pure reason (but not his schematism). Moreover, Nancy adds here an element with a very broad field of application indeed: 'the sic et non of every kind' (D 192). Thus, these examples on their own do not add up to a defined whole. Fortunately however, Nancy also provides a more detailed definition of the coincidentia oppositorum. Its most general law, according to Nancy, is 'that it contains a gap (écart) at its centre'. Nancy immediately applies this idea to the hyphen, and thereby moreover to the 'uncomposable composition' with which he had already brought it in connection. He concludes: 'the trait d'union passes over a void, without filling it' (D 68). Nancy

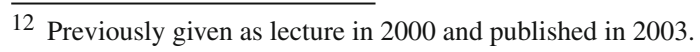


also refers to a 'com-position that would carry within itself, in its cum itself, the law of a deconstruction'. Thus he asks: 'what lies beneath the hyphen and in the hollow of the assemblage?' (D 69).

What Nancy has in mind with this deconstruction carried within the 'com', becomes clear when he explains his reasons for discussing the letter of James. Whereas Lyotard had focused on Paul, who, in Lyotard's view, represented the full extent of the Christian position, Nancy chooses James, who, according to Nancy, really is a transitional figure between Judaism and Christianity. Nancy sets out by noting some facts: 1 . The Epistle of James is the first which may be termed 'catholic', that is, 'directed to all', for unlike Paul, James addresses the whole diaspora. 2. James repeatedly makes positive reference to 'the law which sets us free', but, unlike Paul, never makes a distinction between the 'old' law and a 'new' law. 3. The only overt sign of 'Christianity' are his references to Christ, which appear twice in this letter.

Furthermore, the Epistle of James has become known especially because it can be used to counter an interpretation — which appeals to Paul—which disavows any connection between faith and works. James wonders: 'What good is it, my brothers, if a man claims to have faith but has no deeds? Can such faith save him?' (Jas. 2:14). Nancy observes that James, to the extent that he calls for an active affirmation of faith, places less emphasis on its content. Actually, James does not present us with any theology at all. Nancy therefore concludes that James occupies a position precisely situated between two theologies, two religions, between Judaism and Christianity-a position which represents both their trait d'union and their discrepancy, but also the possibility of their being-together, their com-possibility (D 72-73). With regard to this 'com', Nancy once more notes that it involves both a construction and a deconstruction. According to him, this deconstruction already finds manifestation in James. As a result, he states that the 'Judeo-Christian' of his lecture will be called 'Jacques' (James) (D 70). ${ }^{13}$ At the same time we already get an indication of where Nancy is heading when he states that every composition harbours a deconstruction: it is given with the 'work', with the praxis of existence. We will return to this point in due course. First however, I would like to present a few preliminary observations about the differences between Nancy and Lyotard.

When applying Nancy's idea of a gap in the centre of the coincidentia oppositorum - of a hollow in the assemblage and of a void which he explicitly indicates as not being filled - directly onto the relationship between Judaism and Christianity, it would appear to be essentially no different to Lyotard's contention that between Judaism and Christianity a blank space, or an 'abyss', exists. What strikes us first of all, is that Nancy shifts the discussion with regard to a potential abyss separating Judaism from Christianity, to a discussion of the composite nature of Christianity as such. Put more precisely, Nancy is unwilling to make a distinction between the composition 'Judeo-Christian' and the composite nature of Christianity itself-thus, as if the composition $\mathrm{A}+\mathrm{B}$ is equal to the composite nature of $\mathrm{B}$. While it is true that Nancy does not claim that this composite-ness is a trait exclusive to Christianity or

\footnotetext{
13 With 'Jacques' — as he explicitly states — Nancy not only has James in mind, but also an important guest at his lecture: Jacques Derrida (also see D 65). It is not known whether Derrida appreciated having been referred to as 'the Judeo-Christian'.
} 
Western culture, he does emphasize that the notion of a composite community has always been fundamental to Christianity, and that Christianity is first and foremost responsible for having introduced the notion of the 'pleroma of peoples' into Western culture, or into 'Western-ness' as such (D 68-69). One of the results of this shift is that Nancy dispenses with a conception of Judaism as such.

In the second place Nancy gives no indication of having realized that Lyotard was in actual fact referring to a more fundamental abyss: not the superficially visible difference between the two religions, but the abyss that is felt in aisthèsis, in the estrangement that occurs in aisthèsis. This more fundamental abyss can only be feltas far as knowledge is concerned, it remains concealed. Nancy's views with regard to the composition in no way attests to a consideration of this estrangement. ${ }^{14}$ Moreover, it appears as if Nancy would rather nip such a train of thought in the bud. Evidence for this can be found in his book Etre singulier pluriel (1996). ${ }^{15}$ Of importance is first of all his statement that alterity should not be conceived of as an Other (capitalized). We should not conceive of it as an origin or whatever entity outside of the world, or as a stranger opposed to the own. Thus not as an aliud, alius or alienus, but as an alter, as one amongst many, as everyone every time, as something which every time transforms the world from within. That means, says Nancy, that we should not assume that there is an abyss beyond which lies something prohibited or concealed, or an alienation which needs to be reappropriated - as, according to Nancy, always happens when, some way or the other, the Other is referred to in philosophy. In a footnote (BSP 196) he explicitly states his opposition to Lacan in this regard. As a matter of fact, Nancy's-extremely brief-commentary on Levinas fits the same bill (see footnote on BSP 199). What Levinas understands as 'other than being', is according to Nancy precisely what is most characteristic of 'being'. Thought does not depart from an opposition between the other and being, because being itself is plural right from the very start: after all, as soon as being posits itself, there is being which posits, and being which is posited; in positing, being is at the same time a spacing out and a being-with (BSP 28-32). In as far as being thus should only be conceived of as co-existence, Nancy can see no difference between the ontological and the ethical (BSP 99). Without actually referring to Levinas - but clearly in opposition to Levinas - Nancy states that no ethics is possible separate from ontology, and that only the ontological can be ethical (BSP 21).

It is in these points of departure that Nancy differs from Lyotard. Lyotard draws much of his inspiration from Lacan (specifically Lacan's theorem of the Thing, the Real) and Freud - that is, from psycho-analytic theory in general. In addition, he heavily draws from Levinas and Jewish thinking in general. Especially Lyotard's Heidegger

\footnotetext{
14 The discussion between Lyotard and Nancy affects the choice one has to make in translating Lyotard's phrase quoted by Nancy into English. The French text has: 'l'abîme le plus impenetrable que recèle la pensée de l'Occident'. Now, 'recèle' means both 'entails' and 'conceals'. Nancy appears to ignore the possibility that Lyotard refers to a concealed abyss: the abyss between the Voice and human beings, felt in aisthèsis. Reading Nancy, it is as though Lyotard referred only to the abyss between Judaism and Christianity as such, but this can hardly be called a concealed abyss. Thus, Nancy appears to read the phrase as: 'the most impenetrable abyss that Western thought entails'. In my translation I have chosen 'conceals', because I think this reflects Lyotard's argument more closely.

15 Translated into English as Being Singular Plural, Stanford University Press 2000. For the remainder of this article, this book will be referred to as 'BSP', followed by the relevant page number(s).
} 
et "les juifs" (1988) ${ }^{16}$ provides a clear attempt at combining these two sources. The question is now whether Lyotard's account of Jewish thinking implies that notion of the Other or Outside which is challenged by Nancy. At a first glance this does indeed seem to be the case: a Voice which does not allow itself to be made present, etc. But at the same time we have seen that Lyotard departs from the idea that this estrangement operates within the sphere of life, that is, is being felt and inspires to works, first of all to the work of interpretation. Understood in this way, there is no Other, somewhere else, outside of the world; there is an alterity which is effective in the world. In this regard, the following of Lyotard's remarks is of great importance: 'Jewish listening must remain strained between the inaudible voice of the Other and the entire imaginary realm of the flesh, included in the pact as excluded' (TH 64). Even if Lyotard writes the Other with a capital letter, 'Jewish listening' does not coincide with the Other, but is situated in the space in-between two extremes, between the Other and the imaginary. ${ }^{17}$

We can now return to a closer look at Nancy's conception of alterity, as seen from his reading of the book of James. His reading highlights three themes. First of all I will discuss the theme of the relationship between faith and work, secondly, the relationship between God and man, and, thirdly, the theme of death.

1. The relationship between faith and work has already been briefly discussed. This may be seen as the most important theme of Nancy's essay-as is evident from the subtitle: 'On faith'. The apparent paradox here is that this may just as well have read 'On work'. But Nancy's statement echoes that of James: to talk about faith is to talk about work. James puts it somewhat polemically: 'But someone will say, "You have faith; I have deeds." Show me your faith without deeds, and I will show my faith by what I do' (Jas. 2:18). To Nancy, it is of utmost importance to note which meaning is here being assigned to the word 'work' (ergon). In the preceding verse (2:17) James says: 'Thus also faith by itself, if it does not have works, is dead'. Somewhat further on (Jas. 2:20), in a similar passage, he uses the word argè instead of 'dead'; according to Nancy this is a contraction of aergos: 'without works', 'ineffective'. From this equating of 'without works' and 'dead', Nancy concludes that inversely, work and life, or rather, work and existence, may also be equated: 'the ergon here is existence'. Work not so much entails producing something, but rather being effective, not so much the operari of an opus, but the être-en-acte. Nancy suggests that we ought to reorientate our customary framing of the word 'work'. It is no coincidence that, in James, the word ergon is sometimes translated as 'practice'. Thus, in Aristotelian terms, 'work' is to be assigned to the category of praxis (action, deed) rather than to poièsis (creation, making). Nancy brings several Greek terms together in the following definition: 'pistis (faith) is the praxis that takes place in and as the poièsis of the erga'. 'Should

\footnotetext{
16 Translated into English as Heidegger and 'the Jews', Minnesota University Press, Minneapolis 1990.

17 Actually this discussion ought to be placed within a much wider context. Thus, for instance, already Blanchot in his La communauté inavouable (1983) [The Unavowable Community, Station Hill Press 1988] had delivered a critique on Nancy by appealing to Levinas. Much later Derrida, in his Le toucher, Jean-Luc Nancy (2000) [On touching-Jean-Luc Nancy, Stanford University Press, Stanford 2005] would question, amongst other things, Nancy's deconstruction of Christianity. Also the works of Marion and Henry play an important role in the discussion of Christianity in France. In this regard, the reader is referred to James (2006, Chapters 3 and 4).
} 
I want to frame this in Blanchot's terminology', Nancy continues, 'I would say that faith is the désoeuvrement (unworking) that takes place in and as the work' (D 77). Nancy wants to make it clear here that James' notion of work (as existence, as praxis) entails that work can no longer be viewed as a totality which is closed in upon itself. This may be rendered in Blanchot's terminology as: work 'unworks' itself, it is no more a question of the traditionally 'closed' work (organon) in which all the parts are in tune with one another, but rather a notion of work in which the work opens itself up and becomes 'disorganized'.

Because faith requires work to function within practice, not only poièsis, but also the concept on which the work is based is being transcended. This 'practical excess' in turn provides the working subject with the possibility of being more than (s)he is. But this also means that his or her work cannot be regarded as the property of the subject (D 78). Nancy points out that the most important works referred to by James- the love of one's neighbour, the rejection of wealth, speaking truthfully-all require an exposition to what cannot be appropriated (D 81).

That such a faith transcends the concept—and comprehension in general-means, according to Nancy, that faith must be distinguished from belief: 'faith (foi) cannot be an adherence to some contents of belief (croyance)' (D 78). Against this background, Nancy observes that in James we find a radically different interpretation of Abraham's attitude to that provided by Paul. As a matter of fact, Paul merely quotes from Genesis 15:6: 'Consider Abraham: He believed God, and it was credited to him as righteousness' (Gal. 3:6). To James, on the other hand, what is important is that Abraham actually did something: he presented his son to be sacrificed (Jas. 2:21). In a certain sense, remarks Nancy, James' Abraham did not believe in anything.

To be sure, faith (foi) cannot be separated entirely from the order of logos-the words faith and foi are after all derived via the Latin fides from the Greek pistis, which is in turn derived from the Greek peithô: 'to convince'. But the foi which James has in mind is based upon the inadequacy of its own logos to itself. There are no 'reasons' to believe. 'Faith is not argumentative; rather, it is the performative of the commandment'. The truth of faith, as Nancy puts it, requires first and foremost a 'making-true', a 'veri-fication' (D 79). In short, whereas Nancy is suggesting that Paul conceives of religion as croyance, as believing in the truth of specific statements, as a logos which does correspond to itself, he gives preference to James' notion: faith as foi, as making-true, and as logos which is opened up time and again by practice.

2. James repeats what is stated in Genesis 1:26-27, that man '(has) been made in God's likeness' (Jas. 3:9). In the same passage James confirms that man was created or engendered by God, by referring to God as 'our Lord and Father' (Jas. 3:9). Elsewhere he states 'He chose to give us birth. .., that we might be a kind of firstfruits of all he created' (Jas. 1:18). Nancy interprets the term 'firstfruits' as a distinguishing mark, as a 'trace'. The fact that man has been created in the likeness of God, means that he is the 'homogeneous trace' of the creator (D 74). But a trace signifies a withdrawal from being present. Therefore, the likeness does not entail some kind of mirroring of God and man, of two worlds in isolation from one another; rather, it entails that man within his existence is equal to something which is not present.

James also refers to this 'Father' as 'Father of the heavenly lights, who does not change like shifting shadows', while in the same verse he states that 'every good and 
perfect gift is from above, coming down from the (Father)' (Jas. 1:17). Nancy points out that here God is first and foremost a giver, the giver of light - not of the light reflected from the things in the world, but the light in which these things are possible (D 74). Such a gift is akin, Nancy argues, to 'the grace (which God gives us)' (Jas. 4:6). This gift of grace does not assume the form of a concrete gift, that is, what is being given does not belong to the order of appropriable goods (D 75). The logic of the gift, Nancy states - in reference to 'the other Jacques' (that is, Derrida) - is that the giver, i.e. God, abandons himself (s'abandonne) to the gift (don). Therefore, to be in the likeness of God implies that man gives himself in turn to the gift. That however does not mean that man sacrifices himself (D 76). Nancy consistently criticises the notion of sacrifice as something which implies a second world, a world outside of the world. ${ }^{18}$

3. According to Nancy, James no longer conceives of the divine as an otherworldly presence, as a God inhabiting the rarefied atmosphere of a Mount Olympus or Mount Sinai. Rather, the divine has become the ceaseless threat of death. Towards the end of his letter James writes about the incipient coming of the Lord (5:7-8), about the sick which should be anointed with oil in the name of the Lord $(5: 14)$, the forgiving of sins (5:15) and salvation from death (5:20). The way in which James talks about death reflects, for Nancy, a fundamental shift which was taking place in Antiquity. What begins to establish itself in Western thought is that human existence is no longer being conceived of as mortal in opposition to the immortal, but as a living-dying. Dying 'doubles', so to speak, the time of man's life (D 85). Contrary to what may be said to be characteristic of sacrifice, tragedy and resurrection, in James' view, death is not endowed with a consistency of its own (D 86). Death is no longer a rigid boundary between finitude and infinity. This corresponds well to Nancy's view that finitude and infinity should not be conceived of as two things situated on different sides of a boundary. Instead, as Nancy remarks elsewhere in this volume, finitude is constitutive of the expansiveness and truth of infinity (D 32). With this thought Nancy objects to a dichotomy which tends to transpose everything which cannot be brought to completion in this finite life to a hoped-for life beyond death, on the other side of the boundary — which allows life before death, life on this side of the boundary, to be represented as something self-adequate. In Nancy's interpretation, James also rejects this notion of self-adequacy. Nancy brings this thought concerning the relationship between life and death, finiteness and infinity, in relation to his thoughts concerning work and faith (foi), as opposed to belief (croyance). The idea of life after death is a typical instance of belief (croyance). And according to Nancy, this is not what we find in James. Nancy concludes: 'In the Epistle of James, everything proceeds as though faith ( foi) (...) were the setting into work (mise en oeuvre) of that inadequacy in which and as which existence exists' (D 87). Nancy then winds up his argument: 'The way in which, on a certain day, faith (foi), together with the West, has initiated the composition of a decomposition of religion, places that day before us, a day which is neither Jewish, nor Christian, nor Islamic, but rather like a line (trait) drawn to space out every union' (D 87).

$\overline{18 \text { Cf. Nancy (2003, pp. 51-77). }}$ 
Nancy's point of departure seems convincing to me: every composition or construction harbours a decomposition or deconstruction. Put differently: composition and decomposition come into being at the same moment. This does not detract from the fact that in his account of this composition/decomposition, two models may be distinguished, and it is not at all clear why these two models should be equated with one another. Initially, Nancy explains the composition-on the basis of the coincidentia oppositorum - as something consisting of three elements, namely the two opposite terms and the void between them, which is simultaneously traversed by a hyphen. In the second part of the text the composition is explained rather as consisting of two elements - or even one single element which does not, however, coincide with itself. The second half of his text-that is, from the moment he starts focusing on James' views on work-is characterised by frequent use of the term 'inadequacy'. Nancy's concluding statement, as we have seen, is that existence is inadequate to itself. In concrete terms, the statement expresses that praxis transcends each and every defined entity which we may feel tempted to recognise in it, be it poièsis, the concept, or logos. Precisely for this reason, Nancy assigns primacy to praxis, to work or action.

The primacy of praxis does not mean that Nancy takes recourse to an empirical pragmatism, to the idea that only the 'tangible' quality of action counts for anything. Neither does he appeal to the other extreme, that is, to an 'intangible', suprasensible, 'other' world. Nancy groups together praxis, work, action, experience, faith and existence by assigning to all these things-or more precisely, modes of being - a transcendent involvement with the world. Thus he refers to 'having in this world the experience of something which is not of this world, without however being of another world' (D 120) and of 'opening an outside within this world, without this outside being a world beyond or above this world (D 121). This is a 'transcendence without anything transcendent', a transcendence which is immanent 'to our immanence' (D 198). For Nancy, transcendence comes down to the inadequacy-and therefore composite-ness-inherent to praxis, or to existence as such.

Nancy clearly suggests that this existential inadequacy — strangely enough — is adequately manifested in Christianity; even that Christianity is this existential inadequacy, or-put differently - this living deconstruction. We have already seen that Nancy touches on the issue of the Judeo-Christian composition, but then continues to equate this composition with the composite nature of Christianity itself. And now, in the second part of his text, he has in turn equated the composite nature of Christianity to the composite nature of existence.

\section{Conclusion}

One of the difficulties involved in drawing a conclusion is that Nancy does not focus on Judaism in any detail. A second difficulty is that he does not provide an explicit evaluation of Lyotard's argument. What is however clear, is that Nancy is far more positive than Lyotard in his evaluation of Christianity and Western culture. This is linked to the fact that he chooses to focus on the aspect of openness which, according to him, is fundamental to both Christianity and Western culture. Nancy's most important move is to make James, and not Paul, into his central figure. This allows him to bring his 
own philosophy of praxis and existence into the discussion. What is remarkable is that Nancy's thinking is, in a sense, devoid of history. We already find the deconstruction of Christianity in James; deconstruction and Christianity coincide, so to speak, from the word 'go'. Lyotard, on the other hand, not only distinguishes Judaism, Christianity and modernity as three historically discrete constellations, but he also maintains that all three constellations remain at a distance from the event towards which we always have to find a way of relating.

Up to a certain point, Lyotard and Nancy seem to agree. They both repudiate that view which may be linked to Paul and Hegelian dialectics, namely that Judaism has been sublated into Christianity. For Lyotard, an abyss or blank space is situated between Judaism and Christianity, and in Nancy's view, there is a spacing out of the union and a void which is not filled by the hyphen. With regard to Lyotard, this refers to the first abyss he discusses; with regard to Nancy, it refers to his first exposition of his notion of the 'composition'. However, we have seen that Lyotard also points out a second, impenetrable abyss. This is the estrangement which, according to him, always exists between being 'struck' by a sensation on the one hand, and its representation in knowledge and in interpersonal communication on the other. It is this estrangement to which Judaism gives clear testimony. Is it possible to say that Nancy is also in agreement with Lyotard with regard to this more fundamental abyss? Nancy's first explanation of the composition, of the coincidentia oppositorum - as a space between two extremities-does not even come into consideration. For estrangement is not an opposition, not even an aporia. But can Lyotard's completely unintegratable estrangement perhaps be understood in reference to Nancy's second explanation of the 'composition', that is, as the inadequacy, the immanent transcendence of existence? I think we need to realize that their approaches are radically different. What is at issue in Lyotard, is an alterity which presents itself to us in aisthèsis; in Nancy an alterity which we create in praxis, or in other words, which we create by existing. If one now asks which notion of alterity is to be regarded as the most fundamental one, I think this question is hard to answer. On the one hand, one could say on behalf of Lyotard that there is at least a priority in time, even if coming from 'out of time': the alterity by which we are struck in perception, precedes the alterity which we create. On the other hand, one could say on behalf of Nancy that existing is more fundamental than aisthèsis.

Open Access This article is distributed under the terms of the Creative Commons Attribution Noncommercial License which permits any noncommercial use, distribution, and reproduction in any medium, provided the original author(s) and source are credited.

\section{References}

Badiou, A. (2003). Saint Paul. The foundation of universalism. Stanford: Stanford University Press.

Derrida, J. (2005). On touching_Jean-Luc Nancy. Stanford: Stanford University Press.

James, I. (2006). The fragmentary demand: An introduction to the philosophy of Jean-Luc Nancy. Stanford: Stanford University Press.

Lyotard, J.-F. (1990). Heidegger and 'the Jews'. Minneapolis: Minnesota University Press.

Lyotard, J.-F. (1991). The inhuman. Cambridge, UK: Polity Press.

Lyotard, J.-F. (1999). The hyphen. Between Judaism and Christianity. New York: Humanity Books.

Lyotard, J.-F. (2000). The confession of Augustine. Standford: Stanford University Press. 
Nancy, J.-L. (2000). Being singular plural. Standford: Stanford University Press.

Nancy, J.-L. (2003). The unsacrificeable. In S. Sparks (Ed.), A finite thinking. Stanford: Stanford University Press.

Nancy, J.-L. (2005). La Déclosion (Déconstruction du christianisme, 1). Paris: Galilée.

Weber, E. (1994). Jüdisches Denken in Frankreich. Frankfurt a. M.: Jüdischer Verlag im Suhrkamp Verlag. 